\title{
Studies on The Antibacterial Activity of Some Free and Entrapped Bacteriophages against Fish Pathogens
}

\author{
Sahar W.M. Hassan
}

National Institute of Oceanography and Fisheries, Kayet-bay, Alexandria, Egypt.

\begin{abstract}
THREE DIFFERENT bacteriophages namely VPS1, APS2 and APS3 were isolated from crab (Callinectes sapidus), clams (Tapes decussatns) and fish (Tilapia sp.) samples. They belong to families Siphoviridae, Myoviridae and Podoviridae, respectively. Statistical analysis based on analysis of phages DNA by using random amplification of polymorphic DNA-polymerase chain reaction (RAPD-PCR) revealed that the similarity levels were different among the three phages. Entrapment of VPS1 and APS2 was carried out into calcium alginate beads. The antibacterial activity of VPS1 and APS2 were tested before and after entrapment in Ca-alginate beads against some fish pathogenic bacteria such as Vibrio anguillarum and Aeromonas hydrophila. VPS1 seeded beads were superior (significant at $\mathrm{P}<0.05)$ from the free phages in reduction of the growth rate of $V$. anguillarum while, APS2 seeded beads exhibited lower efficiency in reduction of $A$. hydrophila growth rate. Antibacterial activity of entrapped VPS1 was studied during 7 successive cycles. VPS1 was successful (significant at $\mathrm{P}<0.05$ ) in the reduction of $V$. anguillarum growth rate. A successful trial showed good applicability of entrapped VPS1 in reduction of $97 \%$ of the pathogenic Vibrio spp. in water sample from El-Mex fish farm after $3 \mathrm{~h}$. Chemical characterization of plain and phage seeded beads was performed by using Fourier transform infrared spectroscopy (FTIR).
\end{abstract}

Keywords: Antibacterial, Bacteriophages, Ca-alginate beads. Entrapment.

Aquaculture often suffers from heavy financial losses (Subasinghe et al., 2001; Flegel, 2006 and Saksida et al., 2006) due to the development of infections caused by microbial pathogens, including multidrug resistant bacteria that are easily transmitted through water and therefore able to infect a great variety of fish species.

Different chemotherapeutic agents are used to control microbial diseases. The misuse of them lead to emergence of resistant bacteria in addition to presence of antibiotic residue in the aquatic environment which causing harmful effects on the existing microflora, therefore there is an urgent need to have alternative tools for pathogen control in aquaculture (Sihag \& Sharma, 2012).

E. mail: saharwefky@yahoo.com 
Bacteriophages have long been recognized for their potential as biotherapeutic agents. The major advantages of phage therapy of bacterial disease are host specificity, self replication and environmental safety. The use of phages to control bacterial pathogen depending on the interaction between phages and their bacterial hosts in addition to phenotypic and genotypic diversity (Comeau et al., 2006 and Holmfeldt et al., 2007).

The use of bacteriophages to control bacterial pathogens has previously used with success to control bacterial pathogens in food industry (Greer, 2005; Bahador et al., 2007; Higgins et al., 2007 and Hussain et al., 2008). Phage therapy has been also used to control human and fish pathogens.

A number of phages have been isolated for the potential use in phage therapy in aquaculture (Kumar, 2002 and Nakai \& Park, 2002) against Aeromonas spp. (Imbeault et al., 2006), Vibrio spp.( Vinod et al., 2006; Karunasagar et al., 2007; Shivu et al., 2007; Srinivasan et al., 2007 and Pasharawipas et al., 2011) and Pseudomonas spp. (Park et al., 2000; Nakai \& Park, 2002 and Park \& Nakai, 2003).

The treatment of microbial diseases is still difficult and might involve environmental hazards. A possible method to confront this problem might be the oral administration of antimicrobial materials to the fish larvae through the food chain, using the bioencapsulation technique (Verpraet et al., 1992). It is a physico-mechanical process in which the active components are covered by a layer of another material such as alginate, carrageenan and agarose (Gluza \& Kennedy, 2007).

Immobilized phage could be particularly useful to create antimicrobial surfaces (Cademartiri et al., 2010; Roiha et al., 2010 and Tolab et al., 2010). Immobilized phages were previously used in different applications (Fattouh et al., 2003; Gervais et al., 2007 and Cademartiri et al., 2010).

El-Mex fish farm is a highly economic raring farm. Lately, El-Mex fish farm has been suffered from die-off of large amounts of fish. Different studies attributed this to the presence of high densities of fish pathogens especially Vibrio spp. which cause intestinal infections of fish (Abou-Elela et al., 2005).

The main objective of the present study is to study the antibacterial activity of the isolated phages before and after entrapment in Ca-alginate beads against A. hydrophila and V. anguillarum using the shake-flask method. The potential use of the entrapped VPS1 as bio-control agent of fish pathogenic bacteria in ElMex fish farm will be investigated. The physico-chemical properties of the plain and encapsulated beads with the phages will be determined by FTIR analysis. RAPD-PCR will be also used for investigation and differentiation among the isolated phages. Cluster analysis also will be used to indicate the similarity levels among the isolated phages.

Egypt. J.Microbiol. 47 (2012) 


\section{Materials and Methods}

\section{Sample collection and preparation}

Crab, clams and fish were purchased from the market. Kidneys of fish samples, crab and clams were held at 5 to $10^{\circ} \mathrm{C}$ during shipment for 24 to $30 \mathrm{hr}$ prior to analysis. They were scrubbed, shucked, mixed with an equal $(1: 1)$ weight of Butterfield's phosphate-buffered saline and blended (APHA, 1970).

\section{Phage isolation}

Phages were isolated directly from supernatant of crab, clams and fish kidney homogenates as previously described (DePaola et al., 1997). All media and diluents were prepared in seawater and diluted with deionized seawater. Casamino acids peptone marine (CPM) broth (5.0 g of Casamino Acids [Difco], $5.0 \mathrm{~g}$ of Bacto Peptone [Difco], and 1.0 liter of seawater, autoclaved for $15 \mathrm{~min}$ at $121^{\circ} \mathrm{C}$ ) was used as a growth medium. Serial dilutions of each supernatant were prepared in sterile seawater. Aliquots $(0.1 \mathrm{ml})$ of each dilution were adsorbed to $0.2 \mathrm{ml}$ of log-phase host cultures for $15 \mathrm{~min}$, and virulent phages were detected by using the soft-agar overlay technique (Adams, 1959). The plating medium and soft-agar overlay were prepared with CPM medium supplemented with 1.5 and $0.7 \%$ Bacto Agar (Difco), respectively. The plates were incubated at $30^{\circ} \mathrm{C}$, and plaques were detected at $24-48 \mathrm{hr}$. The plaque types, different in shape and size were isolated, purified and propagated to represent different phage isolates. The titre of each isolate was determined using the double agar layer method.

Electron microscopy examination of the phage isolates

The morphology of the three phage isolates VPS1, APS2 and APS3 was investigated with electron microscopy. Phages were negatively stained with $2 \%$ sodium tungestate in bi-distilled water at $\mathrm{pH}$ 6-7.5. Five $\mu \mathrm{l}$ of each phage was dropped onto a carbon-coated grid. The excess liquid was removed with filter paper after $1 \mathrm{~min}$. Five $\mu \mathrm{l}$ of dye solution was added and after $1 \mathrm{~min}$, the grid was dried. The grids were then examined and electron micrographs taken with a transmission electron microscope (JEOL $100 \mathrm{CX}$ ) operating at $80 \mathrm{kv}$.

Analysis of phage DNA by random amplification of polymorphic DNApolymerase chain reaction ( $R A P D-P C R)$

The purified phage DNA isolated from each phage isolate was analyzed using RAPD-PCR. Amplification reactions were performed in a total volume of $50 \mu \mathrm{l}$ containing $100 \mu \mathrm{M}$ each of dATP, dTTP, dCTP, and dGTP, $0.2 \mathrm{M}$ of each RAPD primer, 25ng of template DNA and 1.25 units of Taq polymerase in $1 \mathrm{x}$ PCR buffer containing $2.5 \mathrm{mM} \mathrm{MgCl}$. The reaction mixtures were subjected to amplification as follows: 45 cycles of $1 \mathrm{~min}$ at $94^{\circ} \mathrm{C}, 1 \mathrm{~min}$ at $37^{\circ} \mathrm{C}$ and $1 \mathrm{~min}$ at $72^{\circ} \mathrm{C}$. After the last cycle samples were maintained at $72^{\circ} \mathrm{C}$ for $10 \mathrm{~min}$. Amplification products were analyzed by agarose gel $(1 \%)$ electrophoresis, stained with ethidium bromide and DNA profiles were documented and analyzed using Alfa Imager $1200 \mathrm{Tm}$. Faint, <1 \% of total intensity, and inconsistent 
bands most likely the result of poor primer-template matching were excluded from the analysis. Amplification reactions were done using one of the following primers 1, 6-d: 5`-(AAGAGCCCGT)-3`; 2, 6-d:5`(AACGCGCAAC)-3`; 3, 6-d: 5 (CCCGTCAGCA)-3`. The obtained results were further analyzed by Pearson Product (Autofit $4 \%$ ) and clustering was also achieved.

\section{Entrapment in Ca-alginate beads}

Entrapment was done in $2 \%$ calcium alginate gel beads as described by Eikmeier \& Rehm (1987). A $25 \mathrm{ml}$ sodium alginate was prepared and then autoclaved at $121{ }^{\circ} \mathrm{C}$ for $10 \mathrm{~min} .1 \mathrm{ml}$ phage suspension was mixed with sodium alginate solution, then homogenized and dropped from a hydrodermic syringe to $100 \mathrm{ml}$ of calcium chloride solution (2\%) to obtain spherical beads of calcium alginate. The formed beads were maintained in the gelling bath to harden for 2 h., then, they were filtered through a Whatman No. 1 paper and washed with sterile distilled water. The resulted beads entrapping the phage were added to 50 $\mathrm{ml}$ CPM containing the exponentially growing bacterial cells. Flasks were incubated at $30^{\circ} \mathrm{C}$ with shaking at $150 \mathrm{rpm}$.

\section{Beads characterization using Fourier transform infrared spectroscopy (FTIR} spectra)

A FTIR spectrophotometer (FTIR-8400S Shimadzu-Japan) was used. Samples were scanned from 500 to $4000 \mathrm{~cm}^{-1}$.

\section{Antibacterial activity of free and entrapped phages}

The test microorganisms were grown at $30^{\circ} \mathrm{C}$ for $24 \mathrm{hr}$ on CPM medium. A cell suspension of each microorganism was used for the antibacterial test. The antibacterial activity was evaluated by using the shake flask method (Ye et al., 2005). In this test, $50 \mathrm{ml}$ of each cell suspension and predetermined amounts of beads were placed in a sterilized flask and continuously shaken at $150 \mathrm{rpm}$ on a rotary shaker. At prescribed time intervals, $1 \mathrm{ml}$ of sample solution from bead/microbial suspension system was removed by pipetting and optical density (O.D) was measured at $550 \mathrm{~nm}$. The optical density of free phage samples was also measured as mentioned above.

Recycling of phage seeded beads

Phage seeded beads were recycled for 7 times in $50 \mathrm{ml}$ CPM containing the exponentially growing bacterial host. Flasks were incubated with shaking at $30 \mathrm{oC}$. Optical density was measured at $550 \mathrm{~nm}$ as mentioned before.

Effect of VPS1 seeded beads on the estimates of Vibrio spp. in water sample from El-Mex fish farm

One $\mathrm{ml}$ of VPS1 seeded beads was added to $50 \mathrm{ml}$ of water sample from ElMex fish farm. The mixture was incubated at $30^{\circ} \mathrm{C}$. Estimates of Vibrio spp. was detected at different time intervals using thiosulphate citrate bile salt sucrose (TCBS) agar and was extended to $96 \mathrm{hr}$. 


\section{Statistical analysis}

Data analysis was performed with the software package Microsoft Excel, Version 2003. Statistically significant difference was determined using paired Student's t-test and $\mathrm{P}<0.05$ was used as a limit to indicate statistical significance.

\section{Results}

Different phages namely VPS1, APS2 and APS3 were isolated from different sources including crab (Callinectes sapidus), clams (Tapes decussatns) and fish (Tilapia sp.) depending on the plaque morphology and size. VPS1 produced small circular clear plaques. APS2 plaques were circular with entire edges. APS3 produced large circular plaques with irregular edges.

The phages were identified by using morphological criteria. Morphological studies revealed that the two phages (VPS1 and APS2) have tails and thus belong to the order Caudovirales. As shown in Fig.1a, VPS1 has icosahedral head and long tail and thus belongs to family Siphoviridae morphotype 1 as it has collar like structure between the head and the tail with no additional appendages on its head or tail. APS2 (Fig. 1b) belongs to family Myoviridae morphotype 2 as it has icosahedral head and long tail with no special appendages. On the other hand, APS3 exhibited different morphology as it has no tail so, it belongs to family Podoviridae (Fig. 1c).

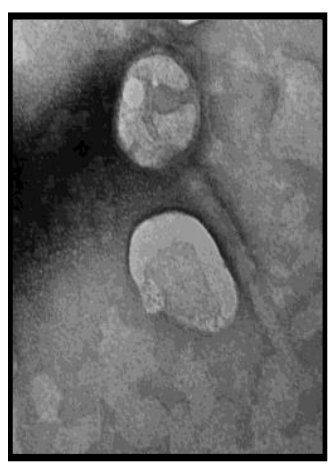

a

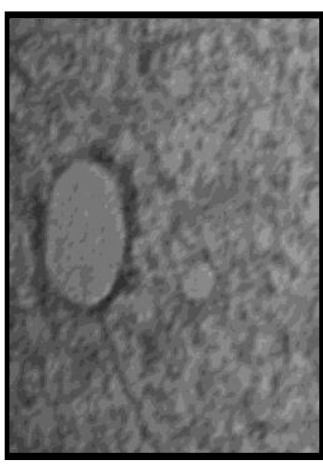

b

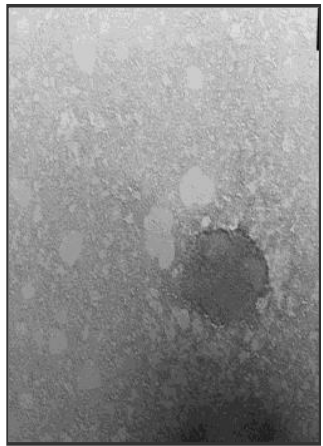

C

Fig. 1. Electron micrographs showing a) VPS1 b)APS2 and c) APS3.

Cluster analysis based on molecular characterization using (RAPD-PCR)

Analysis of phages DNA using Pearson Product (Autofit 4\%) yielded the dendogram shown in Fig. 2. As observed, RAPD-PCR using primer 2 (Fig. 2B) showed that, APS2 was separated at 56.41\% similarity level while VPS1 and APS3 were clustered in one group with $83.81 \%$ similarity. The similarity level increased between the two phages by using the primer 3 (Fig. 2C) to be $96.57 \%$ and APS2 was separated at $53.01 \%$ similarity level. On the other hand, RAPD- 
PCR using primer 1 (Fig. 2A) showed that the similarity level between VPS1 and APS2 was $63.90 \%$ while APS3 was branched out at $52.08 \%$ similarity level .

A

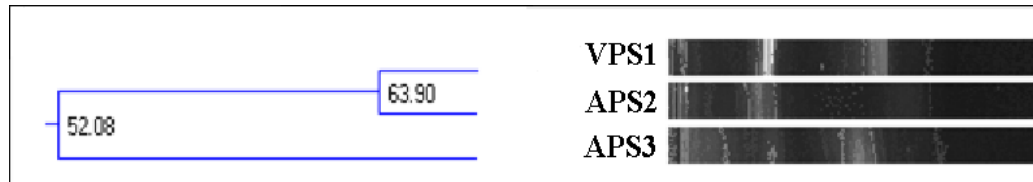

B

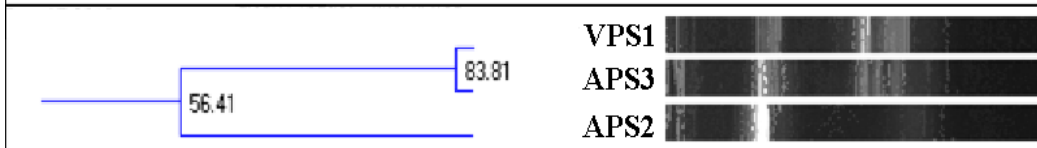

C

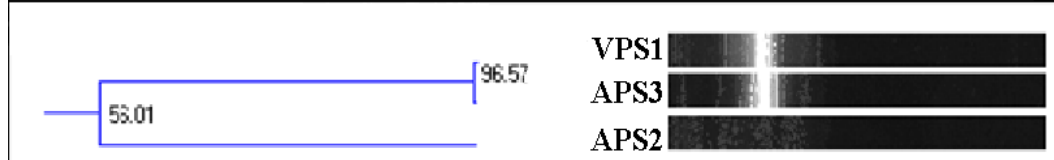

Fig. 2. Similarity levels among VPS1, APS2 and APS3 based on molecular characterization using (RAPD -PCR).

FTIR spectrum of plain and phage seeded beads

In this part of study, FTIR was used to reflect the molecular structure of plain and encapsulated calcium alginate beads. As shown in Fig. 3, Peaks of the plain calcium alginate beads appeared at $1614 \mathrm{~cm}^{-1}$ and $1419 \mathrm{~cm}^{-1}$ assigned to the asymmetric and symmetric carboxylate $\left(\mathrm{COO}^{-}\right)$vibrations, respectively (Fig. 3a). The spectrum shows also some characteristic peaks at $804 \mathrm{~cm}^{-1}, 1276 \mathrm{~cm}^{-1}$ (C-O), $2219 \mathrm{~cm}^{-1}, 2312 \mathrm{~cm}^{-1}$ and $2925 \mathrm{~cm}^{-1}\left(\mathrm{CH}_{2}\right.$ stretching).

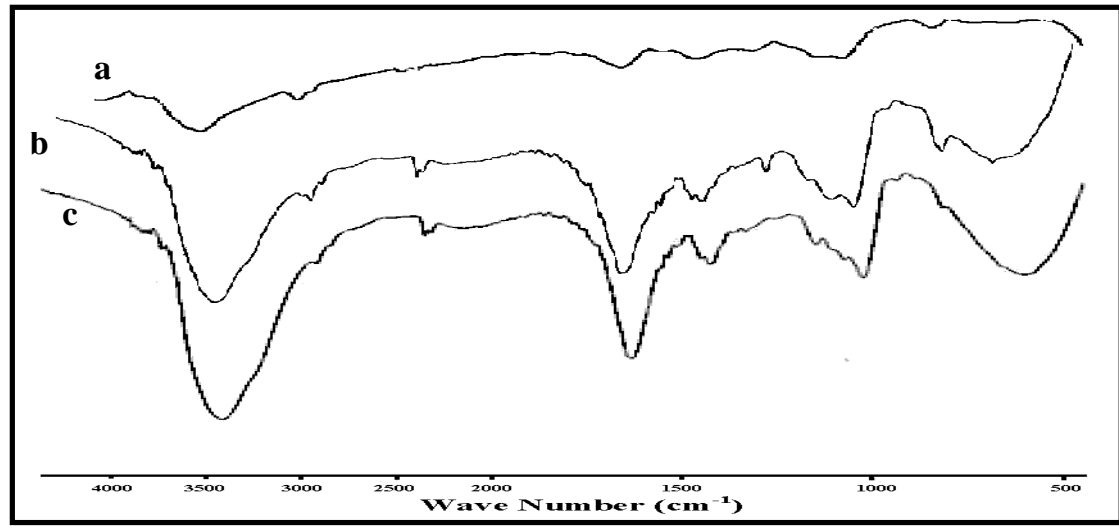

Fig. 3. FTIR spectra of (a) plain Ca-alginate beads, (b) Ca-alginate beads encapsulated with APS2 and (c) Ca-alginate beads encapsulated with VPS1.

Egypt. J.Microbiol. 47 (2012) 
Encapsulated beads with APS2 (Fig. 3b) showed new absorption peaks assigned to stretching vibration of $\mathrm{OH}$ and $\mathrm{NH}$ groups. New peaks were observed at $3834.1 \mathrm{~cm}^{-1}, 3798.3 \mathrm{~cm}^{-1}, 3733.9 \mathrm{~cm}^{-1}$ and $3418.1 \mathrm{~cm}^{-1}$. Also another new absorption peaks were appeared at $667 \mathrm{~cm}^{-1}, 1029.1 \mathrm{~cm}^{-1}, 1084 \mathrm{~cm}^{-1}$, and $1867 \mathrm{~cm}^{-1}$ (C-O bands). Another change was shifting in the position of the peaks such as (COO-) group which was shifted from $1419 \mathrm{~cm}^{-1}$ to $1455.5 \mathrm{~cm}^{-1}$. CH2 stretching groups $\left(2312-2319 \mathrm{~cm}^{-1}\right)$ were also shifted

In case of encapsulated beads with VPS1 (Fig 3c), peaks at $2312 \mathrm{~cm}^{-1}$ were extended to $2338.1 \mathrm{~cm}^{-1}$ (CH2 stretching). Peaks representing (COO-) vibrations at $1419 \mathrm{~cm}^{-1}$ was also shifted to 1431.3 . There were appearance of new absorption beaks assigned to $\mathrm{C}-\mathrm{O}$ bands at $559.9 \mathrm{~cm}^{-1}, 1028 \mathrm{~cm}^{-1}, 1078.5 \mathrm{~cm}^{-1}$, $1152 \mathrm{~cm}^{-1}$ and $1867.3 \mathrm{~cm}^{-1}$. The same for the groups at $3835.2 \mathrm{~cm}^{-1}, 3817 \mathrm{~cm}^{-1}$, $3799.1 \mathrm{~cm}^{-1}$ and $3742 \mathrm{~cm}^{-1}$ which indicate the presence of stretching vibration of $\mathrm{OH}$ and $\mathrm{NH}$ groups.

Antibacterial activity of free and entrapped phages

The aim of this part is to study the effect of entrapment of phages on the interaction between them and their hosts. VPS1 and APS2 were chosen to complete the study based on that they are different and distinct from each other in the morphological and genotypic characteristics. Results showed that the entrapped VPS1 was superior (significant at $\mathrm{P}<0.05$ ) in its effect on $V$. anguillarum than the free phage and caused complete elimination of $V$. anguillarum after $1 \mathrm{hr}$ post addition of the beads as shown in Fig. 4 . On the other hand entrapment of APS2 showed reverse effect and thus the free phage was better (significant at $\mathrm{P}<0.05$ ) than the entrapped one in its reduction to the growth rate of A. hydrophila as shown in Fig. 5.

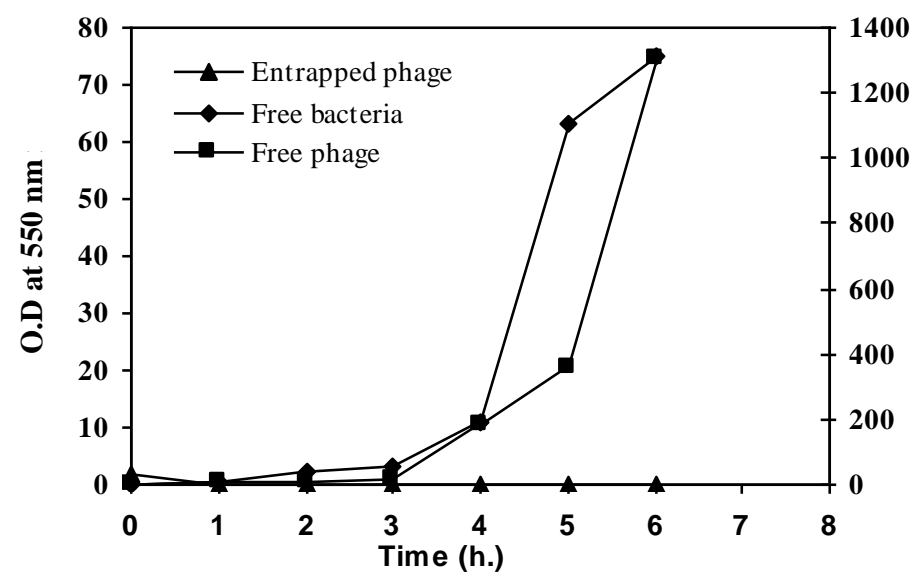

Fig. 4. Effect of free and entrapped VPS1 on the growth rate of V. anguillarum. 


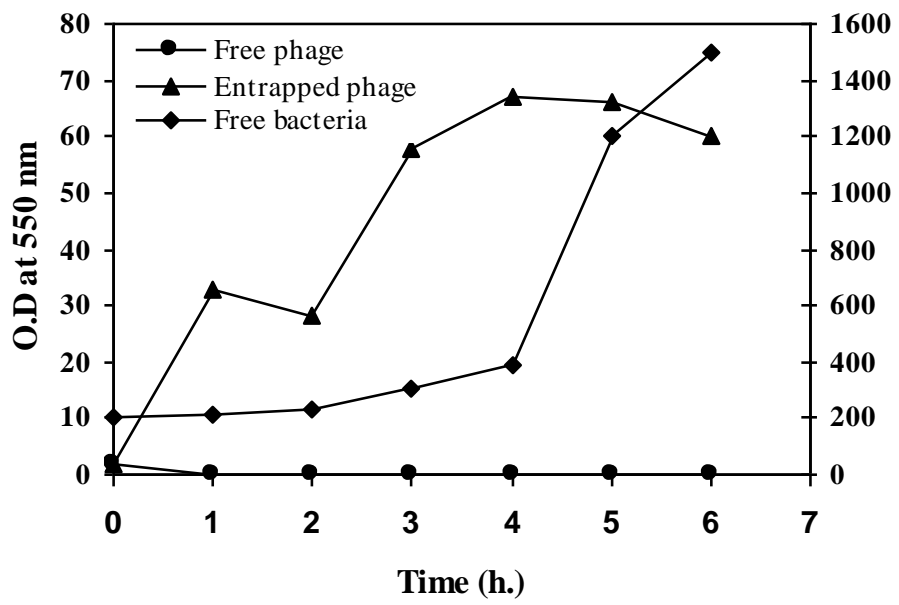

Fig. 5. Effect of free and entrapped APS2 on the growth rate of A. hydrophila.

VPS1 seeded alginate beads were tested for their efficiency in the reduction of the growth rate of $V$. anguillarum for 7 successive cycles. Results (Fig. 6) showed that, the entrapped VPS1 particles were active and caused complete elimination of the host growth rate until the end of the third cycle. They were also able to release and reduce the growth rate of the host bacterium during the rest of the cycles but with lower activity.

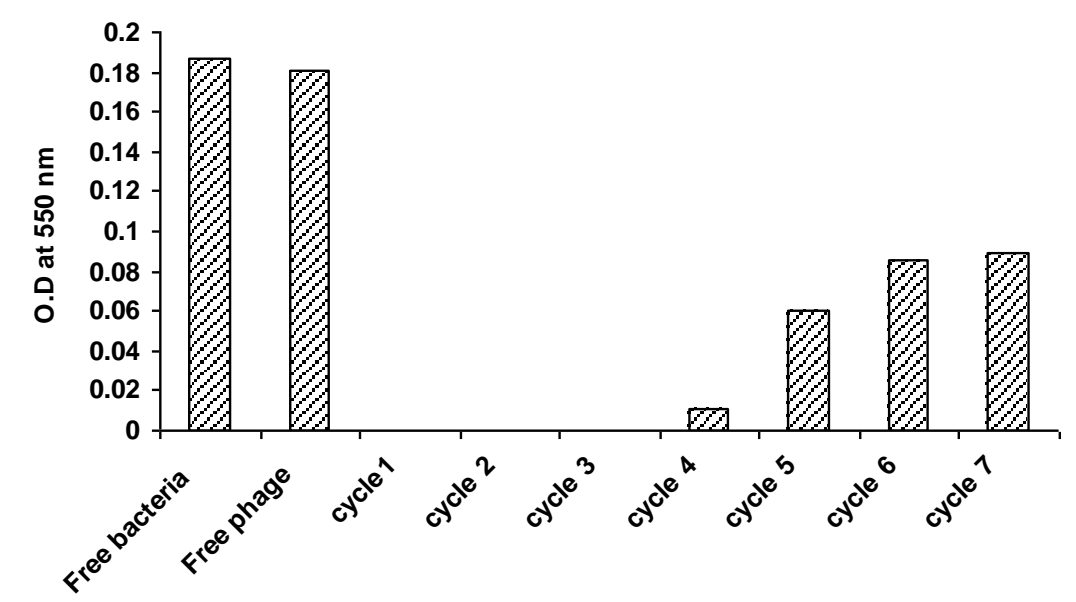

Fig. 6. Recycling of VPS1 and its effect on the growth rate of $V$. anguillarum .

The entrapped VPS1 was tested for their efficiency in biocontrol of Vibrio spp. invading the fish basins in El-Mex fish farm. Results in Fig. 7 indicated that VPS1 seeded beads were able to reduce the counts of Vibrio spp. $2 \mathrm{hr}$ post 
addition of the beads and reached its maximum reduction (97\%) at $3 \mathrm{hr}$ compared to the control and this was confirmed with the statistical analysis using (t-test, $\mathrm{p}$ $<0.05$ ). It was obvious that the effect of entrapped VPS1 extended until $96 \mathrm{hr}$ but with lower efficiency.

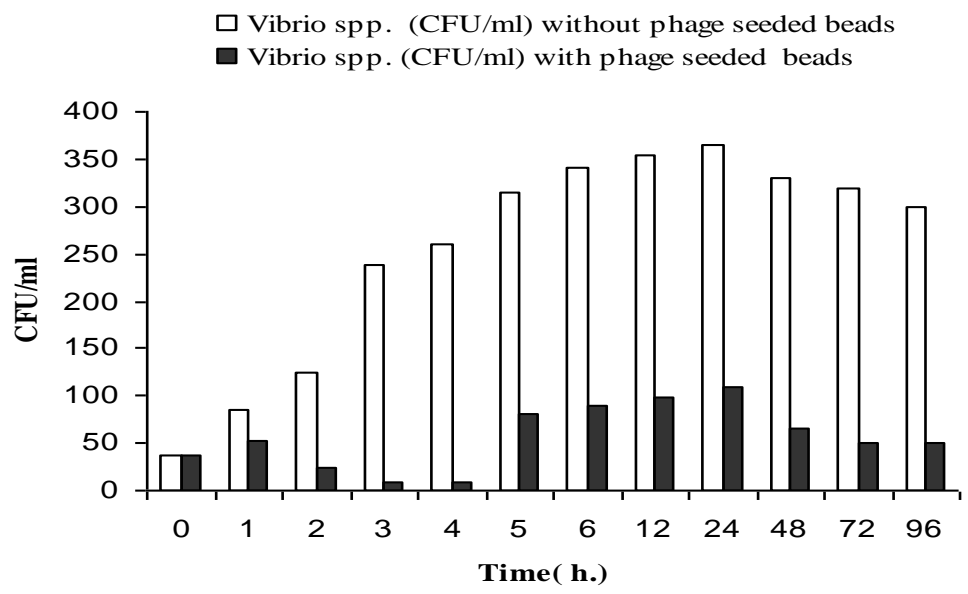

Fig. 7. Effect of VPS1 seeded beads on the count of Vibrio spp.

\section{Discussion}

Bacteriophage therapy of infectious diseases in aquaculture has been suggested in different studies (Kumar, 2002; Nakai \& Park, 2002 and Pereira et al., 2011).

Electron microscopy was used to classify the isolates into their appropriate taxonomic position (Prestel et al., 2012). VPS1 and APS2 assigned to order caudovirales as they have long tail and double stranded DNA. Our results are in accordance with that reported by Mitchell \& Rouf (1983), Fattouh et al. (2002) and Pereira et al. (2011), where the tailed phages predominate other morphotypes. VPS1, APS2 and APS3 were found to belong to family Siphoviridae, Myoviridae and podoviridae, respectively as was proposed by Murphy et al. (1995). Frank \& Moebus (1987) isolated a number of phages belonging to Podoviridae and also DePaola et al. (1998) reported the existence of phages belonging to Podoviridae in bivalves.

Random amplification of polymorphic DNA (RAPD) technique is used extensively for the epidemiological investigation and differentiation of many microorganisms (Jothikumar et al., 1998; Priscilla et al., 2000; Schaper \& Jofre, 2000 and Walter et al., 2000). Presence of polymorphic DNA similarity among the three phages representing the families, Siphoviridae, Myoviridae and Podoviridae confirmed that they are not identical and do not seem to belong to the same species and also reveal evidence of vertical and horizontal gene transfer among populations. The same findings were reported by Fattouh et al. (2002). 
FTIR spectra of plain and encapsulated Ca-alginate beads showed appearance and disappearance of some absorption peaks which indicated the modification in the molecular structure of phage seeded alginate beads compared to the plain beads which confirm the entrapment of the phages onto the beads as was reported by Shobier et al. (2010).

In the present work VPS1 seeded phage beads were efficient in causing complete growth elimination of $V$. anguillarum compared to effect of the free phage and thus representing promising agent for fish disease control in aquaculture. Conversely, other studies reported the better effect of free phage in its reduction to growth rate of its host (Fattouh et al., 2003 and Bielke et al., 2007). The efficiency of the entrapped phage may be attributed to the hydrophobicity of calcium alginate beads (Le-Tien et al., 2004), which retains the integrity of the beads and prevents their degradation over the course of experiment and thus allows more surface of contact between the phage and its host (Kim et al., 2007). In addition to the ability of the phages to release at once and causing infection to the host bacterium.

On the other hand, the entrapped APS2 showed lower efficiency in growth reduction which may be due slower release of phage particles from the beads or accumulation of phage particles in high densities without their immediate release into the surrounding medium as was reported by Fattouh et al. (2003).

Recycling of entrapped VPS1 during 7 successive cycles indicated sequential release of phage particles through the recycling period as was previously reported by Fattouh et al. (2003). The efficiency of the entrapped phage particles decreased upon reuse as was reported by Flood \& Ashbolt (2000) and Fattouh et al. (2003).

The host-phage interaction is an important concept and was previously studied (Flood \& Ashbolt, 2000). The present study showed extended efficiency of the phage in reducing the population of Vibrio spp. in the water sample of El-Mex fish farm up to 4 days compared to the water without inoculation of phage seeded beads which seems to be promising for biocontrol of fish diseases. Analogous results have been reported in some studies where virus sized fluorescent microspheres were dosed into wetland biofilms. Microspheres remained in the biofilm for a period of time of at least 7 months, while being rare in the water phase (Flood \& Ashbolt, 2000). These results and the present findings could suggest that there is a potential for the release of the virus particles due to change in environmental factors or any disturbances in the surrounding medium that could result in active infection.

\section{Conclusion}

The present study revealed that entrapment of VPS1 into calcium alginate beads proved an effective antibacterial activity against the tested fish pathogen

Egypt. J.Microbiol. 47 (2012) 
$V$. anguillarum and could be promising as antibacterial agent to control the growth of fish pathogenic bacteria whereas, the free APS2 showed superior effect against $A$. hydrophila. The use of bacteriophages as an alternative to synthetic drugs could be assayed for aquaculture and for biomedical purposes through further researches and investigations

\section{References}

Abou-Elela, G.M., Elsersy, N.A., EL Shenawy, M. and Abdel-Mawla, E. (2005) Microbial assessment of El-Max fish farm. Egypt. J. Aquat. Res. 31, 171-184.

Adams, M.H. (1959) Bacteriophages. Interscience, New York, N.Y.

American Public Health Association (APHA) (1970) Recommended procedures for the examination of seawater and shellfish, $4^{\text {th }}$ ed. American Public Health Association, Washington, D.C.

Bahador, N., Baserisalehi, M. and Kapadnis, B.P. (2007) Application of phages. Res. J. Microbiol. 2, 445-453.

Bielke, L.R., Higgins, S.E., Donoghue, A.M., Kral, T., Donoghue, D.J., Hargis, B.M. and Tellez, G. (2007) Evaluation of alternative host bacteria as vehicles for oral administration of bacteriophages. Inter. J. Poult. Sci. 6, 758-761.

Cademartiri, R., Anany, H. and Gross-Rahul, I. (2010) Immobilization of bacteriophages on modified silica particles. Biomaterials, 31 (7), 1904-1910.

Comeau, A.M., Chan, A.M. and Suttle, C.A. (2006) Genetic richness of vibriophages isolated in coastal environment. Environ. Microbiol. 8, 1164-1176.

DePaola, A., McLeroy, S. and McManus, G. (1997) Distribution of Vibrio vulnificus phage in oyster tissues and other estuarine habitats. Appl. Environ. Microbiol. 63, 2464-2467.

DePaola, A., Motes, M.L., Chan, A. and Suttle, C.A. (1998) Phages infecting Vibrio vulnificus are abundant and diverse in Oysters (Crassostrea virginica) collected from the Gulf of Mexico. Appl. Environ. Microbiol. 64 (1), 346-351.

Eikmeier, H. and Rehm, H.J. (1987) Stability of calcium alginate during citric acid production by immobilized Aspergillus niger. Appl. Microbiol. Biotechnol. 26, 105-111.

Fattouh, F.A., Saeed, H.M. and Wefki, S.M. (2002) PCR-based DNA fingerprinting analysis of coliphages isolated from sewage polluted seawater in Alexandria. Pakist. J. Biolog. Sci. 45 (5), 938-942.

Fattouh, F.A., El Assar, S.A., Farag, A.E.M. and Hassan, S.W. (2003) Effect of coliphage entrapment on its interaction with the host bacterium. Biotechnol. 2 (2), 94-100.

Flegel, T.W. (2006) Detection of major penaeid shrimp viruses in Asia, a historical perspective with emphasis on Thailand. Aquaculture, 258, 1-33. 
Flood, J.A. and Ashbolt, N.J. (2000) Virus-sized particles can be entrapped and concentrated one hundred fold within wetland biofilms. Adv. Environ. Res. 3 (4), 403-411.

Frank, H. and Moebus, K. (1987) An electron microscopic study of bacteriophages from marine waters. Helgol. Meeresunters, 41, 385-414.

Gervais, L., Gela, M., Allain, B., Tolba, M., Brovko, L., Zourob, M., Mandeville, R., Griffiths, M. and Evoya, S. (2007) Immobilization of biotinylated bacteriophages on biosensor surfaces. Sensors and Actuators B: Chemical, 125 (2), 615-621.

Gluza, K. and Kennedy, J.F. (2007) "Encapsulation and Controlled Release Technology in Food Systems", J.M. Lakkis (Ed.), Blackwell Publishing Ltd., Oxford, UK.

Greer, G.G. (2005) Bacteriophage control of foodborne bacteria. J. Food Prot. 68, 11021111.

Higgins, S.E., Higgin, J.P., Bielke, L.R. and Hargis, B.M. (2007) Selection and application of bacteriophages for treating Salmonella enteritidis infections in poultry. Inter.J. Poult. Sci. 6, 163-168.

Holmfeldt, K., Middelboe, M., Nybroe, O. and Riemann, L. (2007) Large variabilities in host strain susceptibility and phage host range govern interactions between lytic marine phages and their Flavobacterium hosts. Appl. Environ. Microbiol. 73, 6730-6739.

Hussain, K., Masud, T., Maqsud, S. and Mahmood, T. (2008) Characterization of Lactococcus phages from Dahi Whey. Pakistan J. Nutr. 7, 689-694.

Imbeault, S., Parent, S., Lagac, M., Uhland, F. and Blais, J.F. (2006) Using bacteriophages to prevent furunculosis caused by Aeromonas salmonicida in farmed brook trout. J. Aquat. Anim. Health. 18, 203-214.

Jothikumar, N., Cliver, D., Mariam, O. and Tadesse, W. (1998) Immunomagnetic capture PCR for rapid concentration and detection of hepatitis A virus from environmental samples. Appl. Environ. Microbiol. 64, 504-508.

Karunasagar, I., Shivu, M.M., Girisha, S.K., Krohne, G. and Karunasagar, I. (2007) Biocontrol of pathogens in shrimp hatcheries using bacteriophages. Aquacult., 268, 288-292.

Kim, Y.S., Kim, H.W., Lee, S.H., Shin, K.S., Hur, H.W. and Rhee, Y.H. (2007) Preparation of alginate-quaternary ammonium complex beads and evaluation of their antimicrobial activity. Internat. J. Biolog. Macromolecules, 41, 36-41.

Kumar, V.M.G. (2002) Luminiscent vibriosis and its control. MFSc Thesis, University of Agricultural Sciences, Bangalore, p. 68.

Le-Tien, C., Millette, M., Lacroix, M. and Mateescu, M.A. (2004) Modified alginate matrices for the immobilization of bioactive agents. Biotechnol. Appl. Biochem. 39, 189-198.

Mitchell, S. Chow and Rouf. M.A. (1983) Isolation and partial characterization of two Aeromonas hydrophila bacteriophages. Appl. Environ. Microbiol. 45 (5), 1670-1676.

Egypt. J.Microbiol. 47 (2012) 
Murphy, F.A., Fauquet, C.M., Bishop, D.H.L., Ghabrial, S.A., Jarvis, A.W., Martelli, G.P., Mayo, M.A. and Summers, M.D. (1995) Virus taxonomy. classification and nomenclature of viruses. sixth report of the international committee on taxonomy of viruses. Spring-Verlag/wien, Austria. pp.256.

Nakai, T. and Park, C. (2002) Bacteriophage therapy of infectious diseases in aquaculture. Res. Microbiol. 153 (1), 13-18.

Park, S.C., Shimamura, L., Fukunaga, M., Mori, K.I. and Nakai, T. (2000) Isolation of bacteriophages specific to a fish pathogen, Pseudomonas plecoglossicidae, as a candidate for fish disease control. Appl. Environ. Microbiol. 66, 1416-1422.

Park, S.C. and Nakai, T. (2003) Bacteriophage control of Pseudomonas plecoglossicidae infection in ayu Plecoglossus altivelis. Dis. Aquat. Organ., 53: 3339. Sited by isolation and characterization of bacteriophages infecting the fish pathogen Flavobacterium psychrophilum.

Pereira, C., Silva, Y.J., Santos, A.L., Cunha, Â., Newton, Gomes, C.M. and Almeida, A. (2011) Bacteriophages with potential for inactivation of fish pathogenic bacteria: survival, host specificity and effect on bacterial community structure. Mar. Drugs. 9, 2236-2255.

Pasharawipas, T., Manopvisetcharean, J. and Flegel, T.W. (2011) Phage Treatment of Vibrio harveyi: A general concept of protection against bacterial infection. Res. J. Microbiol. 6, 560-567.

Prestel, E., Regeard, C., Andrews, J., Oger, P. and Michael, S. DuBow (2012) A novel bacteriophage morphotype with a ribbon-like structure at the tail extremity. Res. J. Microbiol. 7, 75-81.

Priscilla, E.D., Johnson, S., Zimmerley, T. and Sadowsky, M.J. (2000) Use of repetitive DNA sequences and the PCR to differentiate Escherichia coli isolates from human and animal sources. Appl. Environ. Microbiol., 66, 2572-2577.

Roiha, I.S., Otterlei, E. and Bent, O. (2010) Bioencapsulation of florfenicol in brine shrimp, Artemia Franciscana, Nauplii. J. Bioanal. Biomed. 2 (3), 60-64.

Saksida, S., Constantine, J., Karreman, G.A., Neville, C., Sweeting, R. and Beamish, R. (2006) Evalution of sea lice, Lepeophtheirus salmonis, abundance levels on farmed salmon in British Columbia, Canada. In Proceedings from the International Symposium on Veterinary Epidemiology and Economics XI, Cairns, Australia.

Schaper, M. and Jofre, J. (2000) Comparison of methods for detecting genotype of Fspecific RNA bacteriophages and fingerprinting the origin of faecal pollution in water samples. J. Virol. Methods. 89, 1-10.

Shivu, M.M., Raj, I., Rajeeva, B.C., Girisha, S.K., Karunasagar, I., Krohne, G. and Karunasagar, I. (2007) Molecular characterization of Vibrio harveyi bacteriophages isolated from aquaculture environment along the coast of India. Environ. Microbiol. 9, 322-331. 
Shobier, A.H., Wefky, S., Abdel Ghani, S.A. and EIAshry, E. (2010) Comparative study of the antibacterial activity of Ulva lactuca and Pterocladia capillacea extracts before and after encapsulation in Ca-alginate beads. EJAR. 36 (3), 395-402.

Sihag, R.C. and Sharma, P. (2012) Probiotics: the new ecofriendly alternative measures of disease control for sustainable aquaculture. J. Fisheries. Aqua. Sci. 7, 72-103.

Srinivasan, P., Ramasamy, P., Brennan, G.P. and Hanna, R.E.B. (2007) Inhibitory effects of bacteriophages on the growth of Vibrio sp., pathogens of shrimp in the Indian aquaculture Environ. Asian J. Animal and Veterinary Adv. 2, 166-183.

Subasinghe, R.P., Bondad-Reantaso, M.G. and McGladdery, S.E. (2001) Aquaculture in the Millennium. In : Proceedings of the Conference on Aquaculture in the Third Millennium, Bangkok, Thailand; Subasinghe, R.P., Bueno, P., Phillips, M.J., Hough, C., McGladdery, S.E., Arthur, J.R., Ed.

Tolab, M., Minikh, O., Brovko, L.Y., Evoy, S. and Griffiths, W. (2010) Orinted immobilization of bacteriophages for biosensor applications. Appl.Environ. Microbiol. 76 (2), 528-535.

Verpraet, R., Chair, M., Leger, P.H., Nelis, H., Sorgeloos, P. and De Leenheer, A. (1992) Live-food mediated drug delivery as a tool for disease treatment in larviculture. The enrichment of therapeutics in rotifers and Artemia nauplii. Aquacultural Engineering, 11, 133-139.

Vinod, M.G., Shivu, M.M., Umesha, K.R., Rajeeva, B.C., Krohne, G., Karunasagar, I. and Karunasagar, I. (2006) Isolation of Vibrio harveyi bacteriophage with a potential for biocontrol of luminous vibriosis in hatchery environments. Aquacult. 255, 117-124.

Walter, J., Tannock, G.W., Tilsala- Timisjarvi, A., Roodtong, S., Loach, D.M., Munro, K. and Alatossava, T. (2000) Detection and identification of gastrointestinal Lactobacillus species using denaturating gadient gel electrophoresis and species-specific PCR primers. Appl. Environ. Microbiol. 66, 297-303.

Ye, W., Leung, M.F., Xin, J., Kwong, T.L., Lee, D.K.L. and Li, P. (2005) Novel coreshell particles with poly (n-butyl acrylate) cores and chitosan shells as an antibacterial coating for textiles. Polymer, 46, 10538-10543. 


\title{
دراسـات على النشـاط المضــاد للبكتيريـا لبعض اللاقمـات البكتيريـة
} الحرة و المقيدة ضد ممرضات الأسماك

\author{
سحر وفقى مصطقى حسن \\ المعهد القومى لعلوم البحار و المصايد ـ فرع الأسكندرية ـ الأسكندرية .
}

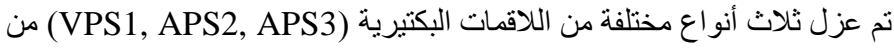

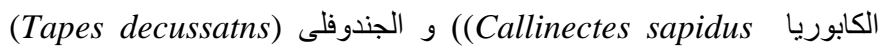

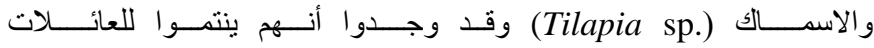

(Siphoviridae, Myoviridae , Podoviridae)

الأحصائى وجود مستويات مختلفة من التثابه بين الثلاث لاقمات وذلك التالك اعتمادا

على تحليل الحمض النوري باستخدام random amplification of

.polymorphic DNA-polymerase chain reaction (RAPD-PCR)

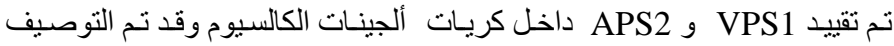

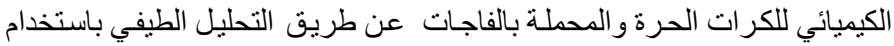

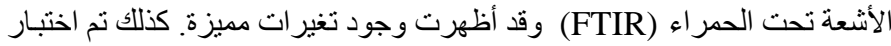

نثـاط اللاقمات VPS1， APS2 ضد بعض البكتيريـا الممرضـة للاسماك مثل فئل

Geromonas hydrophila

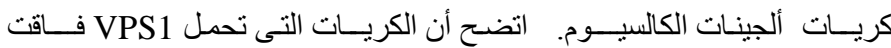

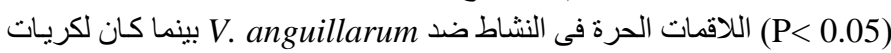

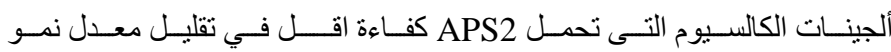

متشع Aeromonas hydrophila

متتابعة وقد لو حظ نجاحه في تقليل معدل نمو Vibrio anguillarum خلال هذه

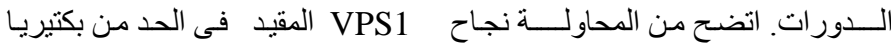

Vibrio 